\title{
ACHIEVEMENTS OF TECHNOLOGY TEACHERS PROFESSIONAL DEVELOPMENT RESULTED FROM AN INTERNATIONAL COOPERATION
}

In the period of the years 2013 - 2017 an international project focused on modernization of tertiary education in Ukraine, Armenia, and Georgia (supported by the European Union in the framework of the TEMPUS program) was carried out. The main goal of the project was to ensure the quality of teaching technical subjects by providing practically oriented syllabi and modules in the embedded system environment and by creating remote laboratories in the target institutions. In accordance with the main goal, great attention was also paid to the professional development of teachers who have been teaching the relevant technology subjects at the concerned higher education institutions. In the paper its authors discuss issues of the evaluation of teachers' competencies in general, describe ways of improvement and development of technical subject teachers' professional competencies in the background of the carried out project, and present results of an analysis aimed at the assessment of the project results achieved with regard to the technical subject teachers.

Keywords: teachers' competencies, professional development, technical subjects teaching, higher education institutions, training courses, curricular innovation, project achievements

\section{Teachers' professional competence}

In literature different terms can be found used by the authors in relation to the teacher career performance, e.g., qualification, professionalism, expertise, mastery or competence [1], [2], [3]. A unifying feature of the use of all these "different" terms is the authors' consistent attitude that teacher's professionalism, qualification, expertise, mastery, competence significantly impact instruction and students' achievements. In general, one can state that success of teaching practice can be measured in terms of teachers' ability to initiate and support learning processes that enable students to achieve specific pedagogical objectives [4].

According to Baumert and Kunter [5], the notion teachers' professional competence covers the qualities that teachers need to meet the demands of their profession. These are related mainly to teachers' pedagogical content knowledge, professional beliefs, work-related motivation, and self-regulation. Within this context, Kleickmann and others [6] stress the difference between the quality of teachers' content knowledge and pedagogical content knowledge, i.e., content knowledge competence and pedagogical content knowledge.
Knowledge of the content (subject matter content knowledge) and teaching of a subject (general pedagogical knowledge) are two key elements of teachers' professional competence (the key competencies, besides the others related to curricular knowledge, knowledge of learners, knowledge of the philosophical and historical goals of education, organizational knowledge and counselling knowledge [7], [8], [9], [10]).

The significance of the content knowledge of a particular subject is partially influenced also by the values accepted by the society and by the role which the relevant science area holds in the society, what are time-depending variables [11], [12], [13].

Academics at higher education institutions (HEIs) are expected to be experts in their science specializations, and at the same time, they are expected to have also an appropriate level of pedagogical competences. But it is a common practice that teaching staff (academics) at higher education institutions usually develop their pedagogic competencies by self-study and by their own teaching practice. In a matter of fact, they are not "qualified teachers", i.e., usually they are not graduates of the teacher training tertiary study programs.

In the frame of the internal quality assurance systems of the HEIs different aspects of the environment, within which the

\footnotetext{
* ${ }^{1}$ Alena Haskova, ${ }^{1}$ Peter Hodal, ${ }^{2}$ Dirk Van Merode

${ }^{1}$ Faculty of Education, Constantine the Philosopher University in Nitra, Slovakia

${ }^{2}$ Technology and Design, Campus de Nayer, Thomas More Mechelen-Antwerpen University College, Sint-Katelijne-Waver, Belgium

E-mail: ahaskova@ukf.sk
} 
HEIs carry out the education of their students, are monitored and assessed. Nevertheless, the key factor staying behind the quality of education are teachers - their professionalism, their teaching mastery, their personalities. That is why evaluation of teachers is included in each quality assurance system of all of the educational institutions. Herein it should be noticed that "all" includes the primary and secondary schools, not only the universities or HEIs. Despite the fact that internal quality assurance systems are usually mentioned with regard to the HEIs, primary and secondary schools have these systems, too. But there is a great difference between the evaluation of teachers at HEIs and primary and secondary schools.

\section{Assessment of teachers' professional competence}

There is no doubt that to evaluate teachers' professional competence is very difficult. There are different aspects based on which it can be done (e.g., portfolios, teachers' written preparations to the lessons), but in a matter of fact, a teacher's competence can be demonstrated and proved only in a practical way, in practice. Additionally to that, independently on the real level of a teacher's pedagogical mastery, the outcomes of his/her teaching are uncertain. They are uncertain in two respects. The first is the fact that instruction always brings some unexpected situations which cannot be planed. A teacher can plan his/ her teaching very carefully, but there is the unpredictability of student's behaviour, classroom discourse, failing of technical support of teaching, etc. And the second is the fact that learning is a mental process with no guarantee of its results (students' learning outcomes), moreover significantly depending on a very broad scope of different factors [14]. The professional practice of teachers is characterized by a lack of standardization, broad scope of non-routine situations and a high level of the uncertainty of success.

At HEIs teachers are assessed not based on their competencies, but rather their performance is assessed. This means that a great attention is paid to their results in the field of research (what can be very easy evaluated through the number of projects they have been involved in, papers and books they have published, patents they have submitted, etc.), and less attention is paid to their teaching results. In comparison to the research performance, to evaluate the pedagogical performance is much more difficult. Of course, it becomes much more difficult when we go beyond the evaluation of the teachers' pedagogical performance in terms of the quantitative indicators, such as the number of lectures and lessons per week, number of students they teach, number of students who do not pass subjects they teach, etc. These numbers do not say anything about the teacher's teaching mastery; they do not assess their professional pedagogical competence.

Completely different is the situation with respect to evaluation of teachers' performance at lower levels of education (primary schools and lower and upper secondary schools, which also have their internal quality assessment systems). There the situation is an opposite one. The key attention is paid to qualitative aspects of teachers' pedagogical performance, to the level of their teaching mastery in all its dimensions, and marginal attention is paid to the evaluation of the teachers' performance based on its quantitative indicators [15].

As to the issue of assessment tools for evaluation of teachers' competencies, these tools are usually developed just with respect to the primary and secondary schools. One of the initiatives devoted to this issue has been a 4-year national project Evaluation of teachers' competencies ran by Constantine the Philosopher University in Nitra. The main aim of the project is to identify a general set of criteria based on which the teachers' competencies should be assessed and to create to them related set of evaluation tools applicable for evaluation of quality and qualification of teachers' pedagogical activities [16], [17], [18], [19], [20], [21]. The set should reflect three basic dimensions of the teachers' professional competencies: competencies related to the learner, competencies related to the educational process and competencies related to professional self-development of teachers. Despite the fact that the set of the assessment tools is designed in the context of the teaching practice ran at primary and secondary school environment, the tools will be applicable also in the environment of the higher education institutions to assess the professional pedagogical competencies of HEIs teachers (of course, not in the dimension of their research activities).

\section{Development of technology teachers competence}

The search for new ways of developing pedagogic mastery of technical subjects teachers at higher education institutions, reflecting the latest trends in teaching technical fields, was one of the main goals of an international project entitled Development of Embedded System Courses with Implementation of Innovation Virtual Approaches for Integration of Research, Education and Production in the Ukraine, Georgia and Armenia (DESIRE project, 2013 - 2017; [22], [23], [24]).

The main coordinator of the project was Thomas More University College (Belgium, BE). Further project partners were one HEI from Germany (DE), one HEI from Slovakia (SK), four HEIs from Ukraine, three HEIs from Armenia, and two HEIs and one research institute from Georgia.

On the basis of good practice and expert activities of partners from the European Economy Area (Belgium, Germany, Slovakia), a change from theoretically oriented teaching of some technical subjects into practically oriented and competencies-developing teaching was to be implemented into the curricula of relevant subjects of relevant study programs taught at HEIs in Ukraine, Georgia and Armenia. As the title of the project indicates, the target study programs and subjects which the particular activities 


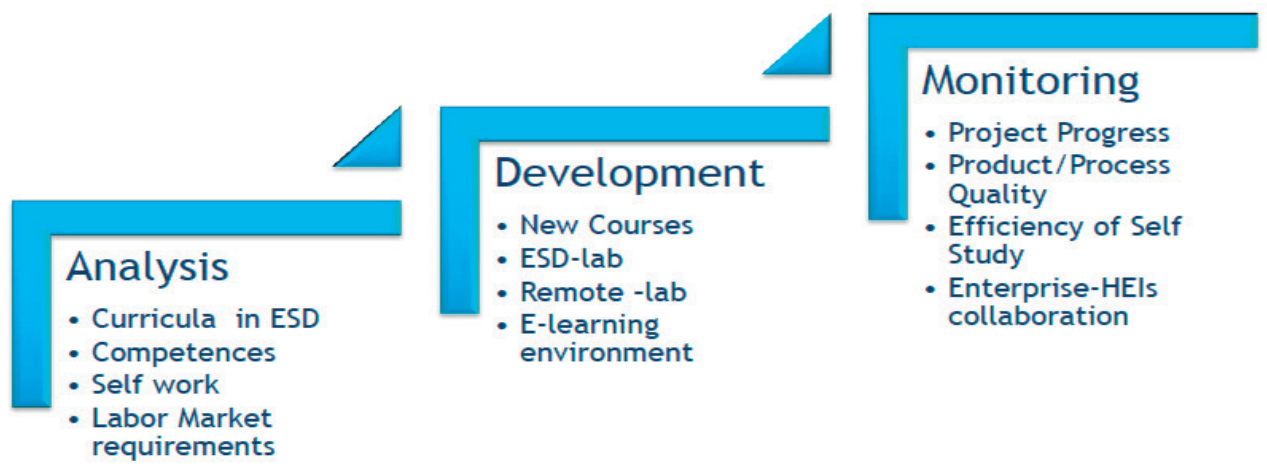

Figure 1 Typology of the DESIRE project activities [23]

of the project were aimed at were subjects or courses majoring in the issue of embedded systems, their programming and their use in different areas. This means that the general aim of the project, i.e., introduction of the change of theoretically oriented teaching of the concerned technical subjects into their practice-oriented and competence-based teaching, was concretized in the specific aims which were:

- to create practice-oriented syllabi and modules of teaching in the environment of embedded systems,

- to establish laboratories of remote experiments in partners institutions in Ukraine, Georgia, and Armenia,

- to develop skills to work with embedded systems required by the labour market.

In accordance with the stated three specific aims the project activities were carried out in three clusters: a cluster of analysis, a cluster of development, and a cluster of monitoring and evaluation (Figure 1).

From the above-mentioned it is clear that besides analysing curricula [25] of the subjects dealing with embedded systems issue (what is taught, how is it taught, when is it taught, with what time/lesson assignment is it taught, what are the expected learning achievements) and establishing new embedded system laboratories equipped with appropriate technical means at HEIs in Ukraine, Georgia and Armenia, a great attention was paid to new ways of the concerned subjects teaching and promoting teaching mastery of teachers who teach them. To provide these teachers new knowledge on latest trends in technical subjects teaching and opportunities to develop their pedagogical competencies, in frame of the project different teaching materials were prepared (e.g. [26], [27], [28]) and several training courses, master classes, for teachers from the Ukrainian, Georgian and Armenian HEIs both abroad (BE, DE, SK) and in the home countries were carried out.

\section{Assessment of the project achievements}

In 2017 DESIRE project was completed. In the frame of the third Monitoring cluster, a final assessment of the project achievements was prepared [22].

\subsection{The methodology of the assessment}

Assessment of the project achievements followed both quantitative as well as qualitative aspects.

The quantitative analysis was based on quantization of the particular indicators of the project results achieved both by the project partners as well as in total. The main observed indicators were the following ones:

- numbers of reviewed curricula / course modules within bachelor / master study programs,

- numbers of students who passed newly developed modules,

- numbers of remote / ESD laboratories developed at the HEI / in co-operation with other education institution / in co-operation with entrepreneur company or stakeholder organization,

- numbers of teaching materials / e-learning materials published at the HEI to assist the newly developed curricula / course modules in embedded systems,

- numbers of successfully defended BA / MA / Ph.D. thesis content-related to the project issue (embedded system design),

- numbers of training hours / training courses / master classes in remote laboratories usage for ESD the HEI participated at / the HEI organized for their students and academics / the HEI organized for other institution members,

- numbers of the participants of the above-mentioned activities,

- numbers of publications related to the project goals and results. 
Table 1 General assessment of the project achievements

Assessment of the benefits of the project

(in short and long-term aspects)

The project created opportunities for future cooperation between institutions involved in the project. Project results have created a platform for further development of distant learning courses and organisation of training courses, e.g., also for employed engineers. Teachers were trained and they mastered fully the relevant issue.

Laboratories and materials developed within the frame of the project are used in current courses, as well as in the design of future study disciplines/courses curricula (currently being under development). Within the scheduled next accreditation processes the HEIs plan to introduce the new master courses into the curricula and bachelor/master programs.

Main benefits of the project in both short and long-term aspects are:

- created modern (embedded system) infrastructure and teaching environment,

- significant investment in laboratory equipment and software,

- development of new embedded system laboratories, virtual laboratories, remote labs network,

- trained/re-trained teachers, an increase of their practical abilities in engineering courses teaching,

- development of methodological supports to the courses,

- modified curricula, updated syllabi,

- new teaching materials,

practice-oriented curricula and modules,

wide usage of the remote laboratory, embedded systems laboratory and e-learning courses for students and teachers,

groups of students getting new skills and knowledge on embedded systems,

introduction of study disciplines relevant to today's education market through the financial and methodological assistance of partners,

- development of robust STEM workforce increased employment in companies requiring market-driven technical skills,

- new study possibilities for different target groups established based on the remote labs,

enhancement of the practical orientation of the courses related to embedded systems,

- implementation of RL technology into the distance learning system (Moodle) to enhance self-learning capabilities of both students and teachers,

- implementation of complex projects by students of different specialties, project-based learning,

- development of research and design direction in preparing students of some IT specializations,

- a significant increase of creative and practical components of the students professional training and education,

- research publication performance of both academic staff and students,

- collaboration between HEI and companies/shareholders,

- enhancements of labour market, enterprise, and university triangle,

- cooperation between EU and target countries in education and research.

Assessments of the weaknesses, limitations, insufficient results

Time limits of the project do not allow to introduce the full set of courses, as it requires not only the development of laboratory installations and stands but also the preparation of teachers, development of new subject curricula development of practical lessons.

Main weaknesses of the project realization are:

- technical and delivery problems (delivery problems caused by the political situation and war conflicts in Ukraine),

- weak previous physical and engineering training of students, particularly low knowledge of mechanics, optics, electricity, circuits, etc.,

- lack of teaching materials in the target countries mother tongues,

- a small number of students involved in the pilot teaching and other project activities,

- low possibilities (in terms of the conditions of the HEIs environment) to continue in the already set relations.

Expected further use of the achieved results (after the project expiration)

Achieved results offer a strong basis for the refinement and advancement of newly established programs/courses in the branch of electrical engineering. They will be used to prepare also some further new/innovated study programs/courses (planned to be submitted for the scheduled next accreditation).

The new laboratory equipment of control systems using embedded systems will be developed, including laboratory stands for remote lab sessions. In this way, joint work of students of different specializations will be improved.

Within the project duration, a tight collaboration between particular national institutions involved in the project was established, and there are all preconditions to broaden this cooperation also in other dimensions (beyond the project issues). 
Besides those mentioned above, a further use of the achieved results is expected in the following areas:

- student and teacher mobility to partner HEIs for further studies and research,

- development of new research projects,

- active collaboration with industry representatives,

- establishment of close contacts with the relevant businesses, and organizations of student internship,

- start-ups establishment,

- submission of a new Erasmus plus KA2 CBHE project on Grid of Online Educational Agents for Embedded Systems Teaching.

Proposals for the next activities

Proposals for the next activities follow/result from the mentioned further use of the achieved project results:

- broaden the involvement of students at work in the embedded systems labs and R-labs,

- to expand research aimed at embedded systems issue,

- accreditation of new study courses,

- establishment of close contacts with business, their involvement in the relevant course development,

- training offered to more teachers using project DESIRE materials and equipment,

- sharing of R-Labs, virtual laboratories and embedded system laboratories with other target groups,

- working together on projects of students of different specializations,

- adaptation of methodological support for various specializations,

- keeping contacts among the DESIRE project partners after the end of the project, development of new perspectives of the cooperation based on the already existing one,

- submission of a new Erasmus plus KA2 CBHE project on Grid of Online Educational Agents for Embedded Systems Teaching (GO-EAST) as a logical, natural continuation of the DESIRE project.

The quantitative analysis of the achieved project results done on the basis of above-mentioned indicators was supplemented by a qualitative (mostly scaled) assessment of several selected main indicators. In this qualitative analysis groups of students and teachers of the project partners HEIs, who took part in the concerned project activities, evaluated the carried out training courses, master classes, newly developed teaching and e-learning materials (assessments related to their content, quality and use done by both groups of the teachers and students), the use of the newly established remote/ESD laboratories (both teachers' opinions and experiences related mainly to their use for student training and education and students' opinions and experiences related mainly to the use of these labs for their own training and education).

The key qualitative analysis was done in the form of a synthesis report based on the partner institutions reports, structure of which consisted of:

- assessment of the benefits of the project (in both short and long-term aspects),

- assessment of the weaknesses, limitations, insufficient results of the project,

- expected further use of the achieved results (after the project expiration),

- proposals of the next activities.

Thereinafter main conclusions of the final synthesis report are presented.

\subsection{Summarisation of the assessment main results}

The final synthesis report involves generalized assessments of the project achievements in the project partners' view. Its main conclusions are presented in Table 1.

\section{Conclusion}

The issue of quality assurance, including assessment of teachers' competencies and ensuring their professional development, concerns not only European higher education institutions but it is a worldwide phenomenon reflecting a rapid increase of education and its values for the public. In this connection, it is necessary that higher education institutions demonstrate their interest in quality and educational standards by providing such study programs and subjects by which they will support internationalization of education, raise the attractiveness of their educational offer and take efforts in connecting theoretical knowledge with real practice. In this context, the DESIRE project has got together all the involved partners to mutual co-operation, contributed to innovation and modernization of the relevant study programs of the concerned HEIs, contributed to the professional development of the technical subject teachers and intensified the synergy between the HEIs and business enterprises in the partner countries. 


\section{References}

[1] COCHRAN-SMITH, M., ZEICHNER, K. (Eds): Studying Teacher Education: The Report of the AERA Panel on Research and Teacher Education. Erlbaum, Mahwah, 2005.

[2] DARLING-HAMMOND, L., BRANSFORD, J.: Preparing Teachers for a Changing World: What Teachers Should Learn and Be Able to Do. Jossey-Bass, San Francisco, 2005.

[3] KENNEDY, M., AHN, S., CHOI, J.: The Value Added by Teacher Education. COCHRAN-SMITH, M., FEIMAN-NEMSER, S., MCINTYRE, D. J., DEMERS, K. E. (Eds): Handbook of Research on Teacher Education, 3rd ed. Routledge, New York, 1249$1273,2008$.

[4] WOOLFOLK HOY, A., DAVIS, H., PAPE, S.: Teachers' Knowledge, Beliefs, and Thinking. ALEXANDER, P. A., WINNE, P. H. (Eds): Handbook of Educational Psychology. Erlbaum, Mahwah, 715-737, 2006.

[5] BAUMERT, J., KUNTER, M.: The COACTIV Model of Teachers' Professional Competence. KUNTER, M., BAUMERT, J., BLUM, W., KLUSMANN, U., KRAUSS, S., NEUBRAND, M. (Eds): Cognitive Activation in the Mathematics Classroom and Professional Competence of Teachers - Results from the COACTIV Project. Springer Science + Business Media, New York, 2013.

[6] KLEICKMANN, T., RICHTER, D., KUNTER, M., ElSNER, J., BESSER, M., KRAUSS, S., BAUMERT, J.: Teachers' Content Knowledge and Pedagogical Content Knowledge: The Role of Structural Differences in Teacher Education. Journal of Teacher Education, 64(1), 90-106, 2013.

[7] SHULMAN, L. S.: Knowledge and Teaching: Foundations of the New Reform. Harvard Educational Review, 57(1), 1-22, 1987.

[8] BROMME, R., RAMBOW, R.: Expert-Lay Communication as Object of Expertise Research: For an Extension of the Psychological Picture of the Expert/Experten-Laien-Kommunikation als Gegenstand der Expertiseforschung: Für eine Erweiterung des psychologischen Bildes vom Experten (in German). SILBEREISEN, R. K., REITZLE, M. (Eds): Psychology 2000: Report on the 42nd Congress of the German Psychological Society in Jena /Psychologie 2000: Bericht uber den 42. Kongress der Deutschen Gesellschaft fur Psychologie in Jena (in German). Pabst, Lengerich, 541-550, 2001.

[9] HERTEL, S.: Consulting Competence of Teachers: Competence Diagnostics, Competence Development, Competence Modelling/ Beratungskompetenz von Lehrern: Kompetenzdiagnostik, Kompetenzforderung, Kompetenzmodellierung (in German). Waxmann, Munster, 2009.

[10] ZAHOREC, J.: Informatics in Education /Informatika vo vzdelavani (in Slovak). SPU, Nitra, 2012.

[11] TAVILLA, I., KRALIK, R., MARTIN, J. G.: A Brief Recollection of Kierkegaard's Testimony on Reformation 500th Anniversary. XLinguae, 11(1), 354-362, 2018; VALCO, M., BOEHME, A. J.: Christian Faith and Science Can Science Enhance Theology? European Journal of Science and Theology, 13(3), 89-97, 2017; KRALIK, R., ROUBALOVA, M., LENOVSKY, L., TUSKA, T., KRALJ-VUKSIC, S.: Taanit Bechorim (Fast of the First-Born) in Rabbinic Judaism. XLinguae, 11(1), 4-7, 2018.

[12] VAlCOVA, K., PAVLIKOVA, M., ROUBALOVA, M.: Religious Existentialism as a Countermeasure to Moralistic Therapeutic Deism. Communications - Scientific Letters of the University of Zilina, 18(3), 98-104, 2016; VALCOVA, K.: Thinking with Kierkegaard about Current Challenges in our 'Practice in Christianity'. European Journal of Science and Theology, 12(2), 203-212, 2016.

[13] VALCO, M., KRALIK, R., BARRETT, L.: Moral Implications of Augustine's Philosophical and Spiritual Journey in his Confessions. Communications - Scientific Letters of the University of Zilina, 17(2), 103-108, 2015; PAVLIKOVA, M.: Kierkegaard's Understanding of Man and Society. XLinguae, 11(1), 323-331, 2018; AMBROZY, M., VALCO, M., BHATTARAI, S.: The Ethical Aspect of Scientific Interest in Selected Physical Theories. Communications - Scientific Letters of the University of Zilina, 19(4), 79-84, 2017.

[14] MCCAFFREY, D., LOCKWOOD, J. R., KORETZ, D., LOUIS, T. A., HAMILTON, L.: Models for Value-Added Modelling of Teacher Effects. Journal of Educational Behavior Stat, 29(1), 67-101, 2004.

[15] MAGOVA, L. et al.: Evaluation of Teachers' Competence in European and Slovak context/Hodnotenie kompetencii ucitelov v europskom a slovenskom kontexte (in Slovak). Verbum, Prague, 2016.

[16] GADUSOVA, Z., HASKOVA, A.: Evaluation of Teachers' Competencies as a Part of School Leadership. Proceedings of International Conference on Communication, Business and Education (CBE 2016), Volume 50 of Lecture Notes in Management Science. Singapore, 7-12, 2016. DOI 10.5729/lnms.vol50.7.

[17] GADUSOVA, Z., HASKOVA, A.: Results of an On-Line Survey on Competence Profiles of Primary and Secondary School Teachers. FOK, W., WENTING LI, V. (Eds): Teaching and Learning with Technology. World Scientific Publishing Co. Pte. Ltd., Singapore, 271-281, 2017. 
[18] Gadusova, Z., HOCKICKOVA, B., LOMNICKY, I., PREDANOCYOVA, L., ZILOVA, R.: Evaluation of Teachers' Competencies. Proceedings of 10th International Technology, Education and Development Conference (INTED 2016). Spain, 6957-6965, 2016.

[19] JONASKOVA, G., HARTANSKA, J., JAKUBOVSKA, V., PREDANOCYOVA, L.: Teachers' Positive and Negative Opinions on Evaluation of their Professional Competencies. Proceedings of 2nd International Multidisciplinary Scientific Conference on Social Sciences and Arts Conference (SGEM 2016). Bulgaria, 1(1), 1241-1248, 2016. DOI: 10.5593/SGEMSOCIAL2016/B11/S03.159.

[20] MUGlOVA, D., MALA, E.: The Positives and the Negatives of Teachers' Evaluation from the Point of View of Evaluators and the Evaluated. Slavonic Pedagogical Studies Journal, 6(1), 22-36, 2017.

[21] VITECKOVA, M., PROCHAZKA, M., GADUSOVA, Z., STRANOVSKA, E.: Identifying Novice Teacher's Needs - The Basis for Novices' Targeted Support. Proceedings of 9th International Conference of Education, Research and Innovation (ICERI 2016). Spain, 7731-7738.

[22] DesIRE Project Website [online]. Available: http://tempus-desire.eu/.

[23] HASKOVA, A., KUNA, P., MALA, E., VAN MERODE, D.: How to Improve Professional Competencies of Technical Subject Teachers. Proceeding of 10th International Conference on Application of Information and Communication Technologies (AICT 2016). Azerbaijan, 536-540, 2016.

[24] HASKOVA, A., VAN MERODE, D.: Professional Training in Embedded Systems and its Promotion. Proceeding of 10th International Conference on Application of Information and Communication Technologies (AICT 2016). Azerbaijan, 718-722, 2016.

[25] NAGYOVA, A., ZAHOREC, J., FERKOVA, S: Some Aspects in Context of Resolving Questions of Innovation of Higher Education in Slovak Republic. Proceedings of 11th International Technology, Education and Development Conference (INTED2017). Spain, 8454-8463, 2017.

[26] KOZIK, T., KUNA, P. (Eds): New Teaching Approaches in Engineering. Proceeding of Lectures of the Summer Course Nitra. UKF, Nitra, 2014.

[27] KOZIK, T., SIMON, M., ARRAS, P., OLVECKY, M., KUNA, P.: Remotely Controlled Experiments. UKF, Nitra, 2016. DOI: 10.17846/RCE2016.178.

[28] KUNA, P., OLVECKY, M., KOZIK, T., (Eds): New Teaching Approaches in Engineering. UKF, Nitra, 2017. 